\title{
HUMAN CAPITAL SPENDING, INEQUALITY, AND GROWTH IN MIDDLE-INCOME ASIA
}

Michael R.M. Abrigo, Sang-Hyop Lee, and Donghyun Park

NO. 529

December 2017
ADB ECONOMICS WORKING PAPER SERIES 


\section{Human Capital Spending, Inequality, and Growth in Middle-Income Asia}

Michael R.M. Abrigo, Sang-Hyop Lee, and Donghyun Park

No. 529 | December 2017
Michael R.M. Abrigo (mabrigo@mail.pids.gov.ph) is a research specialist at the Philippine Institute for Development Studies. Sang-Hyop Lee (leesang@hawaii.edu) is a professor at the University of Hawaii at Manoa. Donghyun Park (dpark@adb.org) is a principal economist at the Asian Development Bank.

This paper has been prepared as background material for the Asian Development Outlook 2017 theme chapter on Transcending the Middle-Income Challenge. 
(C) 2017 Asian Development Bank

6 ADB Avenue, Mandaluyong City, 1550 Metro Manila, Philippines

Tel +632632 4444; Fax +6326362444

www.adb.org

Some rights reserved. Published in 2017

ISSN 2313-6537 (Print), 2313-6545 (electronic)

Publication Stock No. WPS179147-2

DOI: http://dx.doi.org/10.22617/WPS179147-2

The views expressed in this publication are those of the authors and do not necessarily reflect the views and policies of the Asian Development Bank (ADB) or its Board of Governors or the governments they represent.

ADB does not guarantee the accuracy of the data included in this publication and accepts no responsibility for any consequence of their use. The mention of specific companies or products of manufacturers does not imply that they are endorsed or recommended by ADB in preference to others of a similar nature that are not mentioned.

By making any designation of or reference to a particular territory or geographic area, or by using the term "country" in this document, $A D B$ does not intend to make any judgments as to the legal or other status of any territory or area.

This work is available under the Creative Commons Attribution 3.0 IGO license (CC BY 3.0 IGO)

https://creativecommons.org/licenses/by/3.0/igo/. By using the content of this publication, you agree to be bound by the terms of this license. For attribution, translations, adaptations, and permissions, please read the provisions and terms of use at https://www.adb.org/terms-use\#openaccess

This CC license does not apply to non-ADB copyright materials in this publication. If the material is attributed to another source, please contact the copyright owner or publisher of that source for permission to reproduce it. $A D B$ cannot be held liable for any claims that arise as a result of your use of the material.

Please contact pubsmarketing@adb.org if you have questions or comments with respect to content, or if you wish to obtain copyright permission for your intended use that does not fall within these terms, or for permission to use the ADB logo.

Notes:

1. In this publication, “\$” refers to US dollars.

2. Corrigenda to ADB publications may be found at http://www.adb.org/publications/corrigenda 


\section{CONTENTS}

TABLES AND FIGURES

ABSTRACT $v$ V

$\begin{array}{ll}\text { I. INTRODUCTION } & 1\end{array}$

II. EMPIRICAL FRAMEWORK 2

A. Data 2

B. Model 3

III. $\quad$ EMPIRICAL EVIDENCE FROM THE PHILIPPINES CASE STUDY 6

IV. EMPIRICAL EVIDENCE FROM SIMULATION RESULTS FOR ASIA 12

V. CONCLUDING OBSERVATIONS

$\begin{array}{ll}\text { REFERENCES } & 19\end{array}$ 


\section{TABLES AND FIGURES}

\section{TABLES}

$1 \quad$ Human Capital Spending and Inequality: Observed and Simulated 11

$2 \quad$ Human Capital Spending and Fiscal Returns 11

$3 \quad$ Simulated Impact of Human Capital Spending on Productivity Growth and Inequality 15

$4 \quad$ Simulated Fiscal Impacts of Universal and Targeted Human Capital Interventions 16

\section{FIGURES}

$1 \quad$ Labor Income by Age, Income Group, and Residence: Philippines, 2011

$2 \quad$ Human Capital Spending by Age, Income Group, and Residence: Philippines, 2011

$3 \quad$ Human Capital Spending and Number of Children: Philippines, 1991, 1999, and $2011 \quad 9$

$4 \quad$ Human Capital Inequality: Observed and Simulated 10

5 Public versus Private Human Capital Spending in Developing Asia 12

$6 \quad$ Human Capital Spending and Gross National Income per Capita 13

$7 \quad$ Simulated Impact of Increased Human Capital Spending 14 


\begin{abstract}
Asia's rapid population aging fortifies the case for strengthening human capital investments. Further, the experience of the newly industrialized economies suggests that human capital investments will be a vital ingredient of the transition from middle income to high income. Those investments can also affect equity and public finances. In this paper, we use data from the National Transfer Accounts to empirically analyze the effect of human capital investment in Asian countries on economic growth, inequality, and fiscal balance. Our empirical evidence suggests that human capital investments have a positive effect on labor productivity and, hence, output. The positive effect is stronger for poorer households and, hence, beneficial for equity. We also find that such investments can generate sufficient tax revenues to improve the fiscal balance. Overall, our evidence points to a positive effect of human capital on growth, equity, and fiscal balance in Asia.
\end{abstract}

Keywords: Asia, fiscal balance, growth, human capital, inequality

JEL codes: J24, H52, I24, 125 


\section{INTRODUCTION}

One major consequence of Asia's sustained rapid growth is the region's transformation from a lowincome region to a middle-income region in a short span of time. As recently as 1992, more than $90 \%$ of Asia's population lived in low-income countries, but by 2014 , more than $95 \%$ of its population lived in middle-income countries (ADB 2017). The challenge now facing the region is to keep up the growth momentum, and make the next transition from middle income to high income. By and large, the transition from middle to high income is challenging. This explains why many middle-income countries in Latin America and in Asia remain in middle income for a long time, a tendency widely known as the middle-income trap.

One group of middle-income economies that successfully graduated to high income are the newly industrialized economies: Hong Kong, China; the Republic of Korea; Singapore; and Taipei,China. Exceptionally rapid growth enabled the newly industrialized economies to transition from middle to high income in a relatively short period, less than 25 years in the Republic of Korea's case. A large number of empirical and theoretical analyses of possible drivers of this phenomenon almost invariably finds a central role of human capital on economic growth (Mankiw, Romer, and Weil 1992; Barro 2001; and Aghion and Howitt 2009). Further, these studies indicate that government policies played an important role in accumulating human capital and allocating human capital to productive uses. Recent studies find that knowledge capital can also help explain the rapid growth of the East Asian economies (Hanushek and Woessmann 2016).

The rapid aging of Asia's population further strengthens the case for human capital accumulation, and spotlights its potential contribution to economic growth. Intuitively, more productive workers can offset the adverse effect of fewer workers. The share of the elderly population is rising across the entire region, although the current status of population aging still varies a lot across the region. For instance, India and the Philippines are still relatively young, while the People's Republic of China and Thailand have significantly older populations. The Republic of Korea and Singapore are at an advanced stage of demographic transition. Despite such heterogeneity, there is a clear regionwide trend toward older populations and, even in younger Asian countries, the demographic dividends associated with large working-age populations are set to dwindle in the foreseeable future (ADB 2011). The pace of demographic transition is taking place at a very rapid rate in some Asian economies, especially in East Asia. Between 2000 and 2050, the old-age dependency ratio will increase by a factor of six in the Republic of Korea, while it will quadruple in the People's Republic of China. In the absence of significant human capital investments, many aging middle-income Asian economies may see their growth fall sharply.

A shift in population age structure can have two effects on growth. The first demographic dividend is a very direct effect on income and consumption due to a decline in fertility. Over the second half of the 20th century and early 21st century, a secular fertility decline has caused radical and important changes in the population age distribution in Asia and the rest of the world. In the medium term, countries in the early stage of demographic transition have gained from a rising share of the working-age population relative to the young and elderly (Bloom and Williamson 1998, Kelley and Schmidt 2001, Mason 2001, and Mason and Lee 2007). The same demographic forces have improved fiscal health in developing Asia in the short run (Lee, Kim, and Park 2016). 'The second demographic dividend stems from a scaling up of human capital investment and is associated with three main effects:

\footnotetext{
In the longer term, however, populations being increasingly concentrated at older ages will put significant strain on the fiscal system in Asia, not only in countries with especially generous public support systems for the elderly, but also in countries that rely heavily on labor income taxes to finance public consumption.
} 
higher consumption growth, greater physical capital per worker, and better and more human capital. Mason, Lee, and Jiang (2016) estimate these effects and find that human capital is a highly significant channel of this demographic dividend. Both Mason, Lee, and Jiang (2016) and Lee and Mason (2010) find that fertility decline that is accompanied by an increase in human capital investment in children can substantially boost economic growth.

In addition to its effect on economic growth, human capital investment can influence income inequality and fiscal balance. While sustained rapid growth has enabled developing Asia to reduce poverty on an unprecedented scale, the region faces the challenge of rising inequality (ADB 2012). Indeed, the widening income gap between the rich and the poor is a global problem. Lack of education is a major cause of poverty and a deterrent to upward socioeconomic mobility. By strengthening the skills and knowledge of the poor, education can enhance their human capital and earning power, and thus lower inequality. The public sector still provides much of education in most countries. Public education contributes to a country's stock of human capital and enhances the productivity of its workers. Higher labor productivity increases output, and hence taxable income and government revenues. On the other hand, education provision is costly, which explains why education tends to take up a substantial share of the government budget. Therefore, an increase in public sector investment in human capital can either improve or worsen the fiscal balance.

The central objective of this paper is to empirically examine the effect of human capital investment on labor productivity, inequality, and fiscal balance in middle-income Asia. To do so, we use data from the National Transfer Accounts (NTA).

The rest of this paper is organized as follows. Section II presents the empirical framework, i.e., data and model, used for our analysis. Section III reports and discusses a simple case study that simulates the impact of human capital spending on different population groups of the Philippines. The case study allows us to analyze the distributional effects of targeted human capital spending. Section IV reports the simulation results of applying our model to 12 Asian countries. The results suggest that human capital investment not only increases labor productivity and hence output, but also reduces income inequality and improves the government's fiscal balance. Section $\vee$ concludes the paper.

\section{EMPIRICAL FRAMEWORK}

In this section, we describe the data and model we use for our empirical analysis.

\section{A. Data}

Our major source of data is the NTA (www.ntaccounts.org), an accounting framework which documents economic flows across populations of different ages in a manner consistent with the United Nations System of National Accounts (UN DESA 2013). NTA has been estimated for more than 60 countries by an international network of academics, researchers, and government statisticians collaborating under the NTA project. The economic lifecycles are estimated from household surveys and government administrative data, and are scaled to match aggregate controls compiled based on the United Nations System of National Accounts. NTA provides a detailed measure on how much people consume and produce at different ages, and how the gap in their consumption and production is funded through other sources, namely transfers and asset-based reallocations. Except for labor income, NTA distinguish between flows mediated by the private and public sectors. Some early cross-country studies based on NTA include Lee, Lee, and Mason (2008); Mason et al. (2009); and Lee and Mason (2011). 
NTA estimates in current local currency units were converted to constant 2011 United Sates dollars using purchasing power parity factors (World Bank 2016).

Data on human capital spending and labor income are based on NTA lifecycle estimates in 12 Asian economies; namely, Bangladesh, Cambodia, India, Indonesia, the Republic of Korea, Malaysia, Mongolia, Nepal, the Philippines, Thailand, Timor-Leste, and Viet Nam. These economies range from low income to high income, but are predominantly middle income. We measure human capital investments based on NTA estimates of public and private expenditures on education and health at each age. The NTA measure of human capital expenditure might contain some useful information about quality of human capital, an important dimension of human capital. It also allows us to consider both public and private human capital investment separately.

Following Lee and Mason (2010), we include education expenditure for ages 0-26. We only consider health care expenditure for ages $0-17$ to exclude health spending related to reproductive health. It is important to note that NTA estimate of human capital spending only captures goods and services available from the market, and does not include the opportunity cost of time of students or the value of services provided by parents and other family members who contribute to human capital.

Analyzing fiscal effects necessarily requires estimates of tax profiles. NTA distinguishes public transfer flows to and from households by purpose, e.g., education, health, and pension, and by source, e.g., labor income tax, consumption tax, and social security contributions. These estimates are not available for some Asian countries in our sample. As an alternative, we use country-specific personal income tax rates and NTA labor income age profile estimates to construct country tax profiles.

\section{B. Model}

The analysis builds on recent research by Mason, Lee, and Jiang (2016) simulating the impact of the demographic transition on the aggregate economy through greater investments on children, specifically on their human capital. We focus on the impact of expanding human capital investments on both productivity and inequality in developing Asia countries. We also look into how various targeted government interventions to raise human capital may affect fiscal sustainability.

Following Mason, Lee, and Jiang (2016), we specify that the aggregate economy is governed by a production function similar to that proposed by Mankiw, Romer, and Weil (1992)

$$
Y_{t}=K_{t}^{\alpha} H_{t}^{\beta} L_{t}^{1-\alpha-\beta}
$$

where $Y_{t}$ is aggregate output at period $t, K$ is capital, $H$ is human capital, and $L$ is raw labor. As shown in Mason, Lee, and Jiang (2016), the share of production that accrues to labor $Y_{t}^{l}$, as payment for human capital and for basic labor, is given by

$$
Y_{t}^{l}=\beta Y_{t}+(1-\alpha-\beta) Y_{t}
$$

with aggregate contribution of age $x$ as follows:

$$
Y_{t}^{l}(x)=\beta Y_{t} \frac{H_{t}(x)}{H_{t}}+(1-\alpha-\beta) Y_{t} \frac{L_{t}(x)}{L_{t}}
$$


The aggregate stocks of human capital and raw labor are respectively calculated as the sums of their age-specific aggregate stocks, and are given by

$$
\begin{gathered}
H_{t}=\sum_{x} H_{t}(x)=\sum_{x} h_{t}(x) l_{t}(x) N_{t}(x) \\
L_{t}=\sum_{x} L_{t}(x)=\sum_{x} l_{t}(x) N_{t}(x)
\end{gathered}
$$

where $N_{t}(x)$ is population, $h_{t}(x)$ is average human capital stock, and $l_{t}(x)$ is effective labor at age $x$. Note that in the above formulation of human capital stock, increasing average human capital by itself does not necessarily increase the stock of human capital available in the economy. Instead, it must be combined with the effective labor supply. The returns to investing on the human capital of children therefore are not realized until later when children mature, join the labor force, and begin working.

We further assume that the production of human capital is governed by the following production function:

$$
h_{t}(x)=\eta_{i}\left[\phi_{g} l_{g}(x)+\phi_{f} l_{f}(x) e^{z}\right]^{\gamma}+(1-\delta) h_{t-1}(x-1)
$$

where $l_{g}(x)$ and $l_{f}(x)$ are human capital investments by government and households, respectively, and $\gamma \in(0,1)$ is the output elasticity. The human capital stock law of motion in this equation indicates that a unit investment in human capital does not necessarily translate to a unit of human capital. The factoraugmenting technologies $\phi_{g} \geq 0$ and $\phi_{f} \geq 0$ characterize the efficiency of the public and private sectors, respectively, in transforming inputs of human capital investments into units of human capital. Further, similar to physical capital, we allow human capital stock to depreciate at the rate $\delta$ per year. This is an important feature, especially in more advanced ages, and thus adds more realism.

We also introduce heterogeneity among countries, and among individuals within countries, which allows us to analyze the distributional impacts of targeted human capital spending interventions. The parameter $\eta_{i} \geq 0$ captures the differences in human capital production technology across countries, while individual heterogeneity within countries is captured by the random variable $z$, which we assume to be drawn from some zero-mean normal distribution with variance $\sigma_{i}$.

Note that, with the assumption of a Cobb-Douglas production function, the shares of total labor income accruing to human capital and to raw labor are

$$
\begin{gathered}
\frac{H_{t}}{Y_{t}^{l}}=\frac{\beta}{1-\alpha} \\
\frac{L_{t}}{Y_{t}^{l}}=\frac{1-\alpha-\beta}{1-\alpha}
\end{gathered}
$$

Expression (3) may be combined with (7) and (8) to calculate the share of labor income at each age group. This is the same expression used in Mason, Lee, and Jiang (2016) to estimate age-specific labor supply.

$$
\frac{Y_{t}^{l}(x)}{Y_{t}^{l}}=\frac{\beta}{1-\alpha} \frac{H_{t}(x)}{H_{t}}+\frac{1-\alpha-\beta}{1-\alpha} \frac{L_{t}(x)}{L_{t}}
$$


The expression in (3) may also be restated in per capita terms by dividing both sides of the equation by the age-specific population.

$$
\frac{Y_{t}^{l}(x)}{N_{t}(x)}=\frac{H_{t}(x)}{N_{t}(x)}+\frac{L_{t}(x)}{N_{t}(x)}
$$

We estimate the parameters of $h_{t}(x)$, and $l_{t}(x)$ based on restrictions imposed by equations (7), (8), (9), and (10), using simulated method of moments. To simplify our estimation, we limit the parameter space we are estimating by setting the production elasticities $\alpha$ and $\beta$ to be both equal to one-third, based on earlier estimates by Mankiw, Romer, and Weil (1992), and following Mason, Lee, and Jiang (2016). For our baseline estimates, we follow the assumption of Mason, Lee, and Jiang (2016) that public and private human capital spending are equally effective by setting $\phi_{g}=\phi_{f}=1$, and we show how the results vary when we increase the efficiency of publicly provided human capital investment. Finally, we assume $\delta$ to be 0.02 .

Estimation of the rest of the parameters are done in two stages. First, we estimate $\gamma$ and $\eta$ using NTA estimates of labor income, and public and private human capital spending per capita age profiles for 58 economies estimated for a recent year. For each economy in our sample, we simulate 10,000 individuals by drawing a series of random shocks for equation (6) from a standard normal distribution, which are held constant throughout the estimation. The random shocks are then used to calculate the moments implied in equations (7), (8), (9), and (10). These simulated moments are stacked to form the vector $P^{M}(\gamma, \eta)$. Next, we calculate the analogues of $P^{M}(\gamma, \eta)$ from the data in the vector $P^{D}$. Following Meghir and Pistaferri (2004), we estimate $(\gamma, \eta)$ by minimizing the objective function:

$$
Q(\gamma, \eta)=\left[P^{M}(\gamma, \eta)-P^{D}\right]^{\prime}\left[P^{M}(\gamma, \eta)-P^{D}\right]
$$

Note that $\gamma$ and $\eta$ may be seen as average estimates for all economies in our sample. Also, the distribution of private human capital investment shocks is the same for all countries. To provide countryspecific estimates of $\eta$ and $\sigma$, we repeat the above procedure for each economy separately, but this time holding $\gamma$, in addition to $\delta, \alpha, \beta, \phi_{g}$, and $\phi_{f}$, fixed. We modify the moment conditions in (11) by including an additional restriction to allow us to estimate $\sigma$ for each economy. More specifically, we match the simulated labor income Gini coefficient from the model with the observed income Gini coefficient in each of the economies in our sample. The estimated parameters are then used to simulate the impact of raising human capital spending on labor productivity, income inequality, and fiscal balance.

In addition to the above model, we also employ a heuristic model using the Philippines as a case study. The model is based on subnational NTA estimates. Let $l_{g}(x, j), l_{f}(x, j)$, and $y_{l}(x, j)$ be the average public and private human capital investments, and labor income, respectively, at each age $x$ for an individual from some class $j$. In this naïve simulation, we assume that the labor income age profile is directly linked to the schedule of human capital investments, such that increasing human capital spending in some class $k$ to match the higher spending in some class $l$ leads to class $k$ individuals earning labor income at the same schedule as class $l$ workers. We apply this model using recent subnational Philippines NTA estimates calculated for terciles of household income by residence location (Abrigo et al. 2016). This application takes advantage of the increasing availability of subnational NTA estimates, and is in line with recent work which simulates the economic impact of counterfactual economic lifecycle schedules on specific subpopulations (Mejia-Guevara 2014; and Miller, Saad, and Martinez 2016). 


\section{EMPIRICAL EVIDENCE FROM THE PHILIPPINES CASE STUDY}

In this section, we report and discuss the empirical results from a case study based on subnational data from the Philippines. Average labor incomes by age, socioeconomic class, and residence are presented in Figure 1. The labor income age profiles include earnings and benefits of employees, both those working locally and abroad, and self-employment labor income, as well as imputed wages of unpaid family workers. This measure captures age variations in labor force participation, hours worked, productivity, and other factors that influence labor supply decisions. Typical of labor income age profiles, it starts from zero when young, increases in adulthood, peaks at prime age, and then declines as people retire from the labor market.

Figure 1: Labor Income by Age, Income Group, and Residence: Philippines, 2011
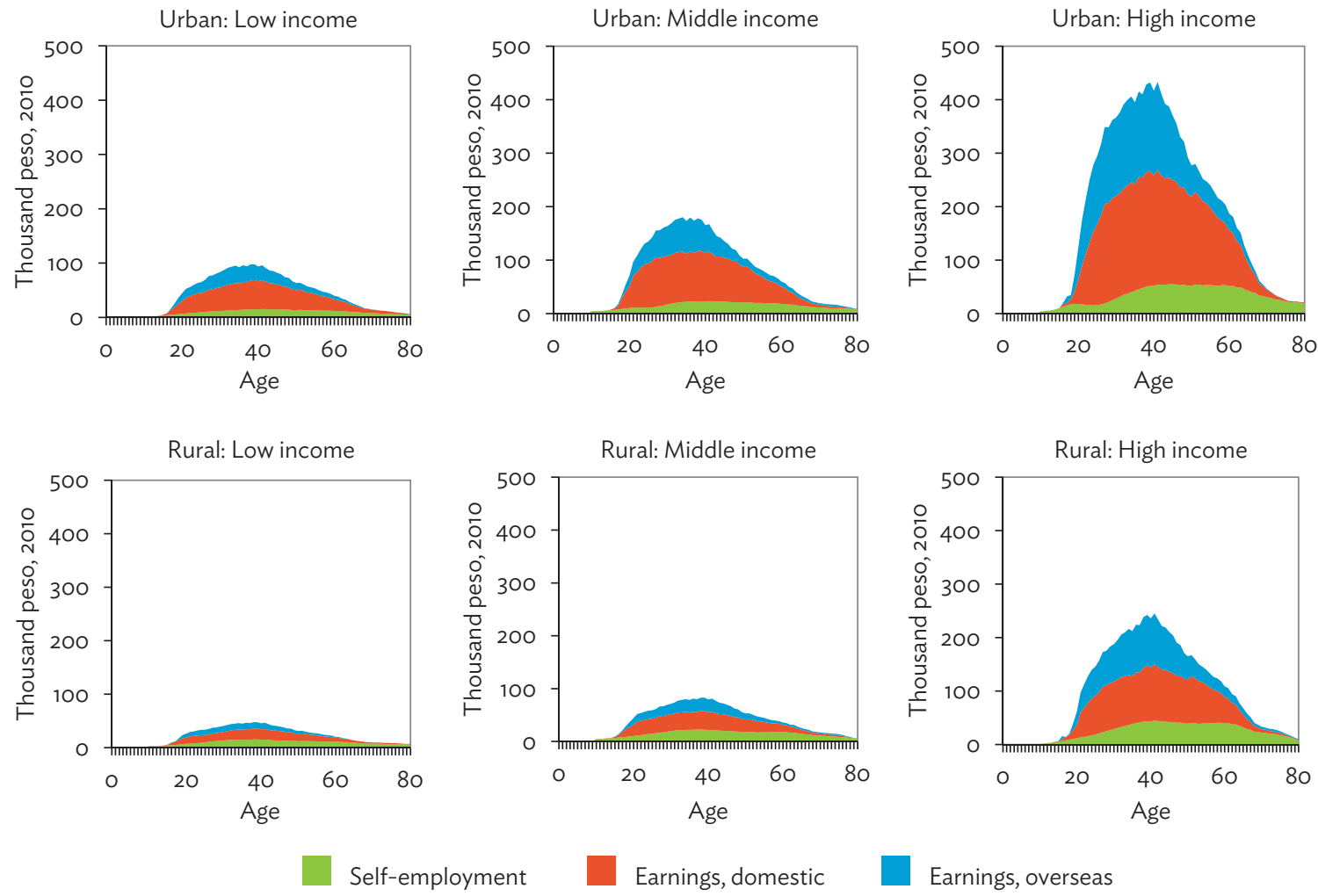

Source: Abrigo et al. (2016).

The figure highlights not just stark differences in overall levels of income, but also important differences in labor income sources, and timing of labor force entry and exit. For instance, at peak productive ages, the average labor incomes of workers from rich households are about quadruple those from low-income households in both rural and urban areas. As workers move up the socioeconomic ladder, we see labor income to be increasingly compressed toward a narrower age band, reflecting the increasing importance of paid employment in the formal economy in labor income. This trend may also reflect the degree of availability of different support systems accessible to populations at either end of the economic lifecycle. For example, schooling keeps the young from working, but poverty may induce children to leave school and work for pay. Insufficient pension income may induce the elderly to continue working to support their consumption. 
Among poorer households, self-employment labor income is an important source of support, accounting for as much as 36\% of total labor income among low-income rural households, and as much as $18 \%$ for low-income urban households. The share of self-employment in total labor income declines progressively with socioeconomic status as more workers enter formal labor markets, including those overseas. Among rich households, earnings from overseas employment account for about a third of total labor income in both rural and urban households. This share declines as one moves down the socioeconomic ladder, although it remains substantial. Among low-income rural households, earnings from temporary international migration accounts for about $29 \%$ of all labor income, while the figure is $23 \%$ for low-income urban households. It is noteworthy that the age profile of overseas labor income peaks at younger ages relative to the age profile of local labor income, indicating the age-based selectivity of international labor migration.

These differences in labor income profiles across subgroups are likely to persist into the future when we consider current human capital spending patterns. Figure 2 presents the age profile of average human capital spending by socioeconomic status and residence. Public and private spending on health and education are separated to compare and contrast differences across subpopulations. Similar to the labor income age profiles, there is large disparity in human capital spending across groups, with per capita spending by age increasing with socioeconomic status, and between rural and urban households.

Figure 2: Human Capital Spending by Age, Income Group, and Residence: Philippines, 2011
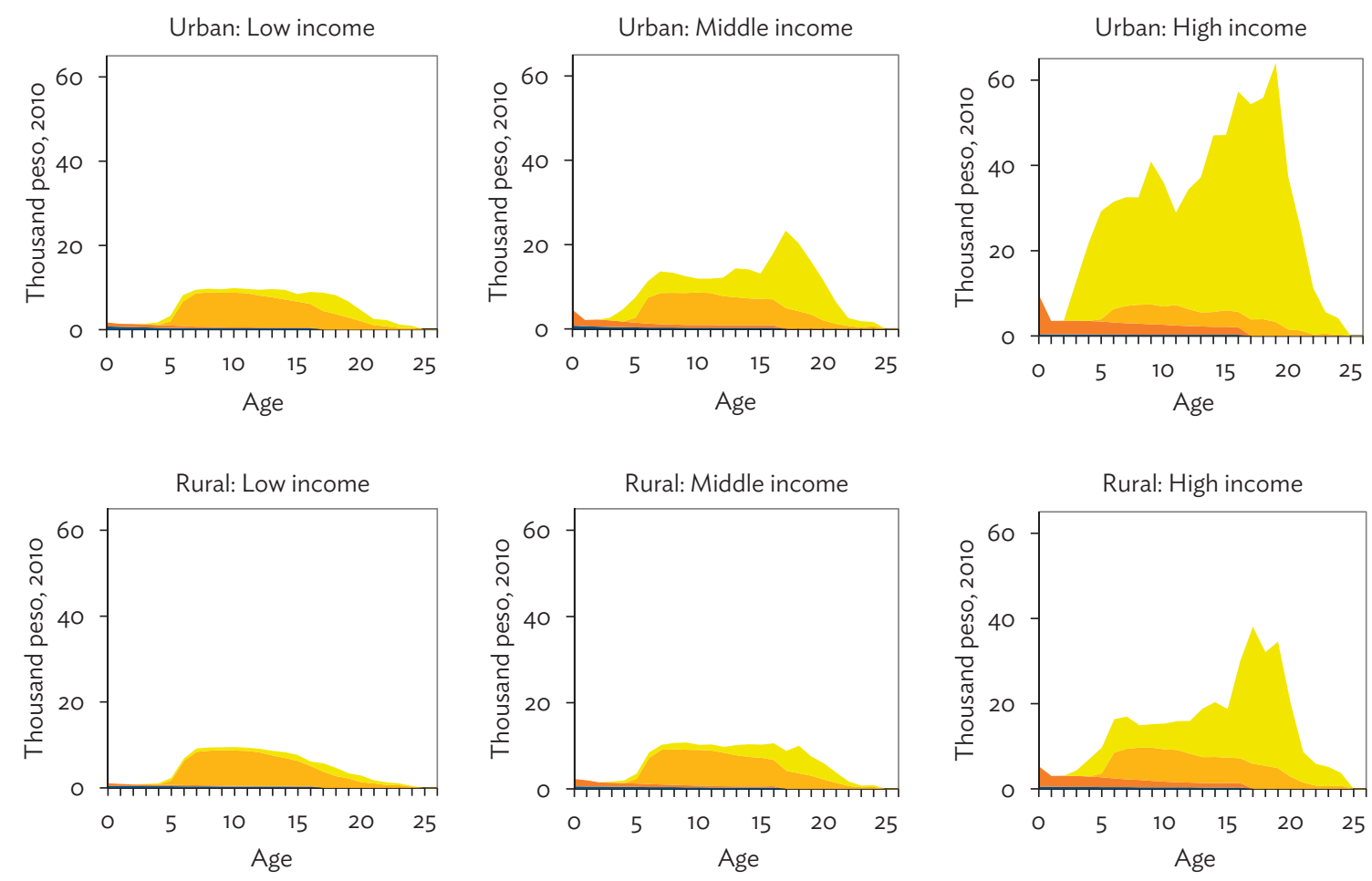

Education, Private

Education, Public

Health, Private

Health, Public 
Human capital spending forms a substantial share of total consumption. Among low-income rural households, for instance, $10 \%$ of total consumption is human capital spending. The share ranges between $6 \%$ and $8 \%$ in other socioeconomic groups. Among poorer households, public provision of health and education is an important aspect of investment in children, accounting for about $71 \%$ of total human capital spending among low-income urban households, and about $82 \%$ among low-income rural households. Among richer households, public provision plays only a secondary role, with about $92 \%$ of human capital spending on children in rich urban households and about $73 \%$ in rich rural households done privately.

In terms of type of spending, education accounts for over half of human capital investments, although a significant uptick in health spending on infants and children is evident from the human capital spending age profiles of rich households. Public spending is largely skewed toward basic education, which partly reflects high public school participation rates, and partly reflects the government budget allocated to each education level. Private education spending, on the other hand, is more concentrated in postsecondary education.

The observed differences in human capital investments across subgroups, to some degree, may reflect their demographic conditions. Lee and Mason (2010), for instance, using cross-sectional NTA data of human capital spending and fertility, estimate that a 1\% drop in fertility is related to about a $1 \%$ increase in lifetime human capital spending. This negative relationship between number of children and human capital spending can also be observed in the Philippines, not only in the cross-section data but also in time series data.

Figure 3 shows a plot of human capital spending per capita summed over the relevant ages by socioeconomic status and residence. The synthetic cohort estimates of human capital spending spans 2 decades. The right-most estimates for each group are for 1991 and the left-most estimates are for 2011. We use the ratio of young dependents ages $0-24$ to adults ages 25 or higher as proxy for fertility. The number of young dependents per adult has declined over the years covered. At the same time, human capital spending has increased, although the increase has been more rapid among richer households, who coincidentally have lower young dependency ratio. While the plot does not indicate the direction of causation between the number of children and human capital investments, it does reflect a strong relationship between the quantity and the quality of children.

How can targeted human capital spending interventions alleviate the current disparity in human capital across the population? We experiment with alternative scenarios where average human capital spending and labor income age schedules of lower-income households are replaced by spending and income patterns of higher-income households. This allows us to evaluate the possible impact of targeted interventions to raise human capital spending in lower-income households. The profiles are all based on 2011 Philippines subnational NTA estimates. We assume that the increase in human capital spending is borne entirely by the government. 


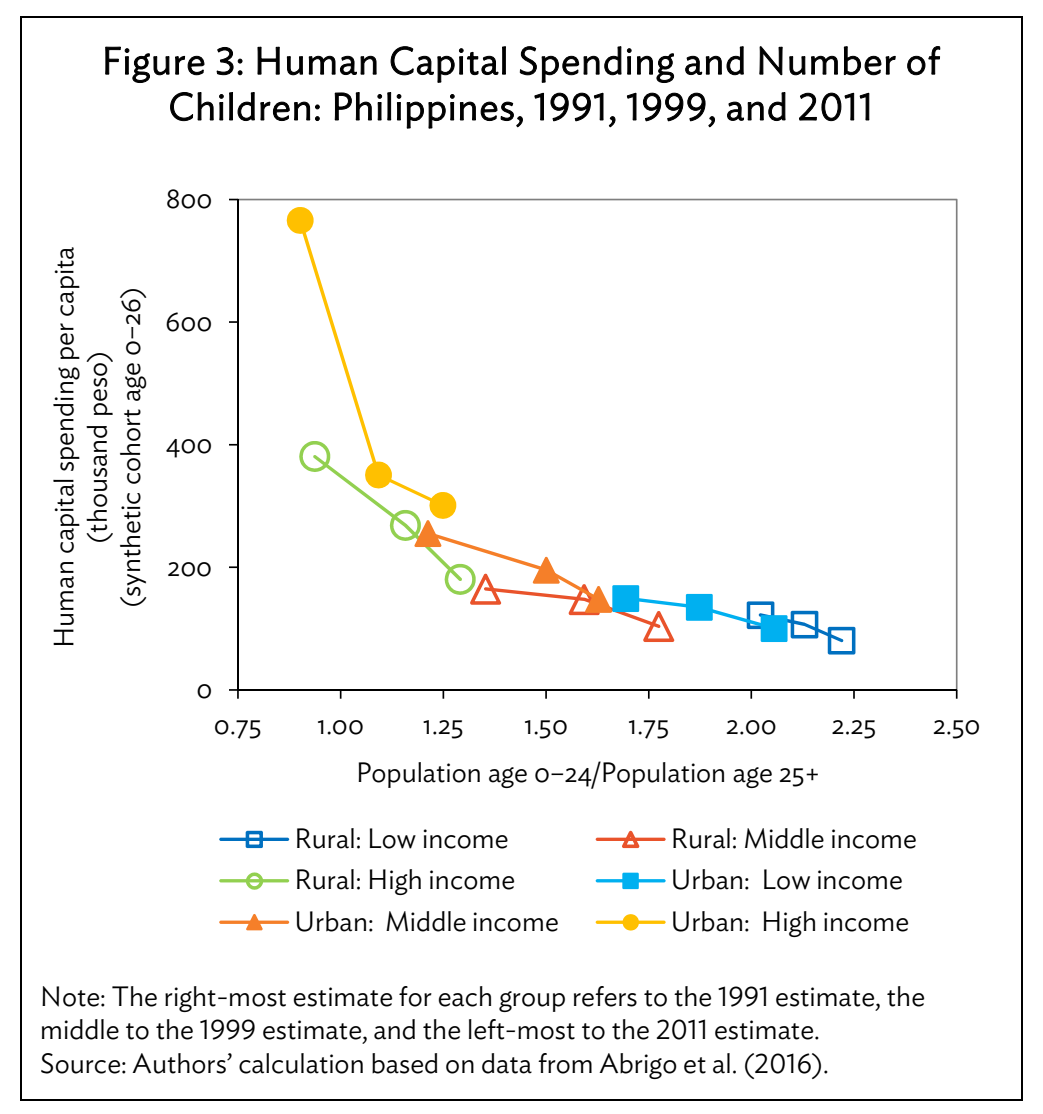

We consider three scenarios. In the first scenario, average human capital spending and labor income age schedules of rural households are replaced by those of urban households. In the second scenario, the age profiles of lower-income populations are replaced by the age profiles of the next higher-income class in our analysis, i.e., low-income profiles are replaced by middle-income profiles, and middle-income profiles are replaced by high-income profiles. In the last scenario, age profiles of lowincome urban households and of low-income and middle-income rural households are replaced by the age profiles of middle-income urban households. We then compare how the resulting distribution of human capital spending would change relative to a baseline scenario of no change in human capital spending.

Figure 4 presents concentration curves of human capital spending under our four different policy scenarios. The concentration curve plots the cumulative distribution of human capital spending, representing benefits, on the vertical axis, and the cumulative distribution of population age 26 and below sorted by socioeconomic status, representing benefit recipients, on the horizontal axis. A concentration curve above the 45-degree diagonal line indicates that the distribution of human capital spending is progressive, where spending on poorer households is larger than their share of the recipient population. A curve below the 45-degree line indicates that richer households receive a higher share of the total human capital spending.

Panel A presents the observed benefit incidence of human capital spending in 2011. The plot indicates that total human capital spending is regressive. When disaggregated by source, we see that the disparity is largely due to private spending, which is highly skewed toward richer households. Total human capital spending by government appears to be neutral. However, there are some nuances when the distribution of public human capital spending is further disaggregated. When broken down by age, 
public human capital spending is more progressive for younger children, i.e., those in basic education, and slightly regressive for older children, i.e., those in higher education. This feature has been documented earlier in the Philippines (Manasan, Cuenca, and Villanueva-Ruiz 2007), as well as in other countries (Davoodi, Tiongson, and Asawanuchit 2010).

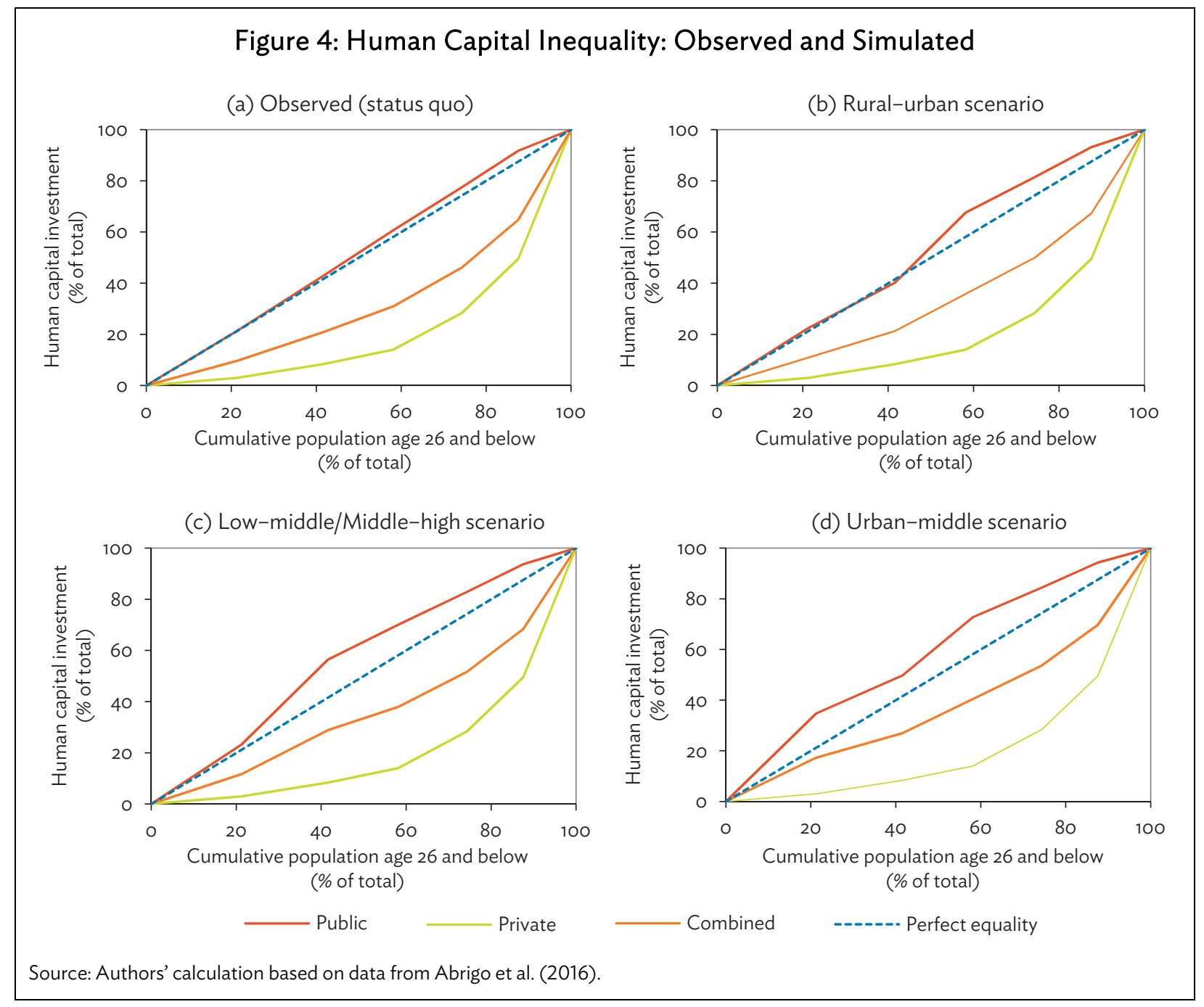

In panels $\mathrm{B}, \mathrm{C}$, and $\mathrm{D}$, we show the corresponding change in concentration curves under our specified alternative scenarios. The concentration curves for private spending do not change across scenarios since we assume that the additional spending is borne by the government. Overall, the plots indicate that targeted spending alleviates inequalities in human capital investments as a result of propoor public human capital spending. However, there are some qualitative differences. Results from our simulation show that the urban-to-rural (panel B) and the low-to-middle/middle-to-high (panel C) targeted human capital spending scenarios are likely to benefit middle-income households more than low-income households. Setting a minimum level of human capital spending age schedule (panel D), which here we peg at the spending level of middle-income urban households, will benefit the poorest the most.

The concentration curves in Figure 4 are summarized in Table 1 by calculating the implied Suits index. The index ranges from -1 to 1 , where a value of -1 indicates that all human capital spending goes 
to the poorest person in the economy, while a value of 1 signifies that all spending goes to the richest person. At baseline, combined public and private human capital spending's Suits index is at 0.19. This is comparable with the 0.24 estimated by Mesa (2007) using years of schooling in 2000.

The estimated Suits index confirms our earlier observation, based on concentration curves, that targeted spending interventions reduce human capital inequality. Depending on the scenario, the Suits index for total human capital spending drops by $2-5$ percentage points. This is due to public human capital spending becoming more progressive, with the Suits index ranging from -0.01 to -0.05 from a baseline value of 0.01 . Because of the higher spending among lower-income households, average lifetime human capital spending per person is projected to increase between $9 \%$ and $58 \%$ of the baseline level, with the government funding $45 \%-62 \%$ of the total spending from the baseline $40 \%$.

Table 1: Human Capital Spending and Inequality: Observed and Simulated

\begin{tabular}{lcccccc}
\hline & \multicolumn{2}{c}{ Human Capital Spending } & & \multicolumn{2}{c}{ Suits Coefficient } \\
\cline { 2 - 3 } \cline { 5 - 6 } Simulation Scenario & $\begin{array}{c}\text { Combined } \\
\text { (\% of baseline) }\end{array}$ & $\begin{array}{c}\text { Public } \\
\text { (\% of total) }\end{array}$ & & $\begin{array}{c}\text { Combined } \\
\text { Spending }\end{array}$ & $\begin{array}{c}\text { Public } \\
\text { Spending }\end{array}$ \\
\hline Baseline (status quo) & 100.0 & 40.0 & & 0.19 & 0.01 \\
Rural-urban scenario & 108.9 & 44.9 & & 0.17 & -0.01 \\
Low-middle/Middle-high scenario & 158.4 & 62.1 & & 0.15 & -0.05 \\
Urban-middle scenario & 128.3 & 53.3 & & 0.14 & -0.05 \\
\hline
\end{tabular}

Source: Authors' calculation.

The increased human capital spending is projected to boost labor income by about $30 \%-50 \%$ of the baseline value. This effectively increases the tax base. Table 2 summarizes the projected impact of our targeted interventions on the government's fiscal position. On a per person basis, lifetime personal income tax is projected to increase between $42 \%$ and $155 \%$ of the baseline value. Effective tax rates will also increase by 2-6 percentage points of the baseline $9 \%$ as more income may be taxed at higher tax schedules.

Taking the costs of additional public spending into consideration, each additional government peso invested in human capital is projected to bring in additional P1.08-P1.11 for the government in personal income taxes. Even with higher tax rates levied on income, households are still projected to benefit from the increased public human capital spending, with post-tax rate of return ranging between $13 \%$ and $16 \%$. The government, in turn, may further benefit from the increased spending of households through taxes levied on consumption of goods and services.

Table 2: Human Capital Spending and Fiscal Returns

\begin{tabular}{|c|c|c|c|c|}
\hline \multirow[b]{2}{*}{ Simulation Scenario } & \multicolumn{2}{|c|}{$\begin{array}{c}\text { Average Lifetime Personal (Labor) } \\
\text { Income Tax Per Person }\end{array}$} & \multicolumn{2}{|c|}{ Internal Rate of Return (\%) } \\
\hline & $\begin{array}{c}\text { Level } \\
\text { (\% of baseline) }\end{array}$ & $\begin{array}{l}\text { Effective Tax } \\
\text { Rate (\%) }\end{array}$ & Fiscal & $\begin{array}{l}\text { Individual } \\
\text { (post-tax) }\end{array}$ \\
\hline Baseline (status quo) & 100.0 & 8.9 & $\ldots$ & $\ldots$ \\
\hline Rural-urban scenario & 142.2 & 11.2 & 10.8 & 16.1 \\
\hline Low-middle/Middle-high scenario & 255.0 & 15.0 & 7.6 & 13.1 \\
\hline Urban-middle scenario & 183.9 & 12.8 & 8.6 & 15.0 \\
\hline
\end{tabular}

$\ldots=$ Not available

Source: Authors' calculation. 


\section{EMPIRICAL EVIDENCE FROM SIMULATION RESULTS FOR ASIA}

In this section, we report and discuss the results of simulating the effect of increasing human capital spending on labor income, income inequality, and fiscal balance for 12 Asian countries. Figure 5 plots lifetime public and private human capital investments in Asia and in other countries where NTA estimates are available. For cross-country comparability, we normalized the values relative to the average labor income of persons ages 30-49. This allows us to control cross-country differences, including labor costs, which are important in the production of education services (Mason, Lee, and Jiang 2016). Estimates below (above) the 45-degree line indicate greater share of the private (public) sector in financing human capital spending. Estimates that are closer to (more distant from) the origin signify smaller (greater) human capital spending in total.

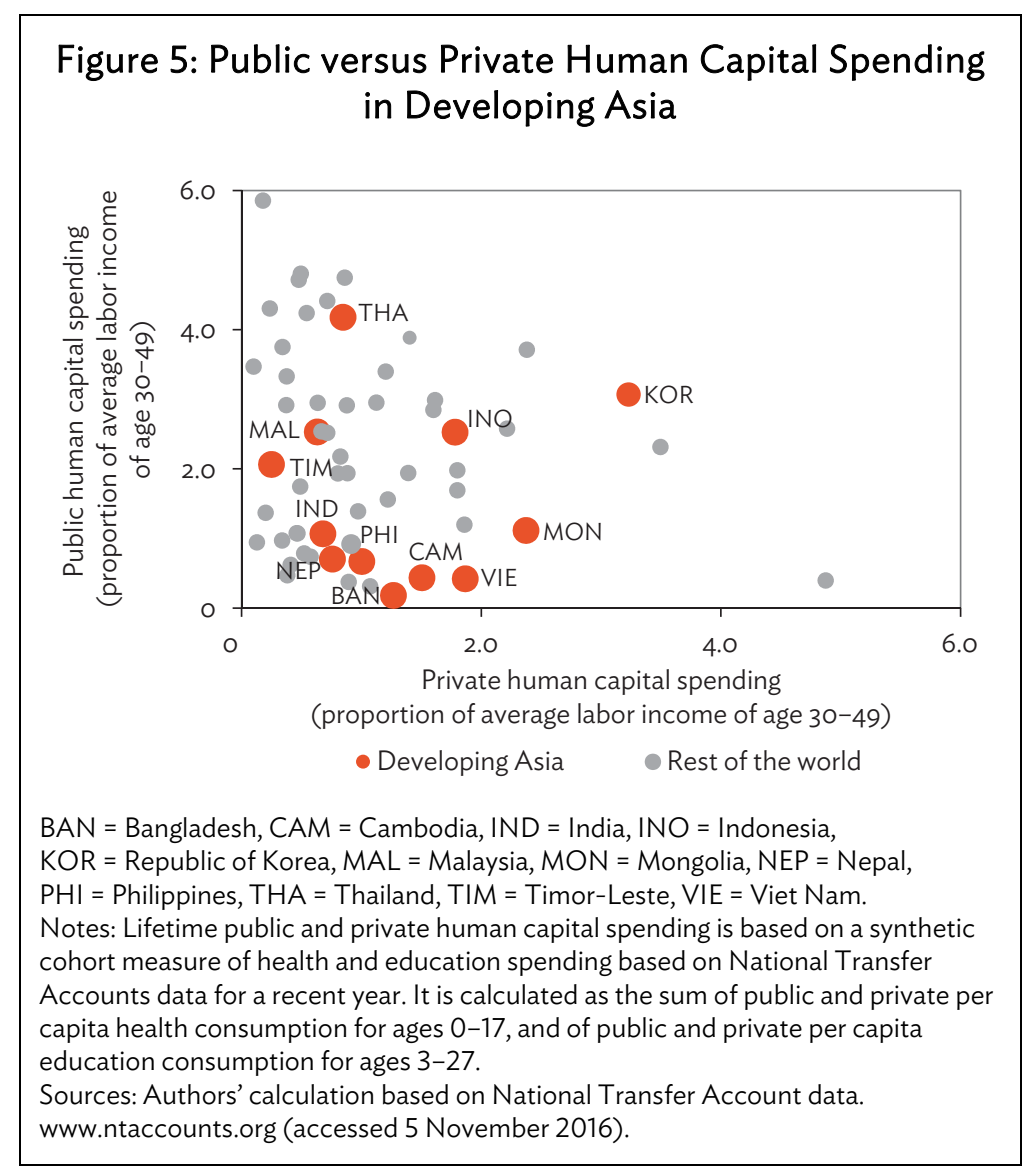

Human capital spending in Asia varies greatly from country to country, both in level and in financing source. Thailand, for instance, invests on average about 5 years of prime-age labor income on human capital for each person. In Bangladesh, on the other hand, the average lifetime human capital spending per person is only 1.4 years of prime-age labor income. Viet Nam and Timor-Leste spend about 2.3 years of labor income on human capital per person, but Viet Nam relies largely on private spending rather than on government. The variations in human capital spending are, to some extent, related to each country's level of economic development. 
Figure 6 plots each country's average lifetime human capital spending against its per capita gross national income. Two observations are self-evident. First, higher-income countries invest more on human capital per person (panel A). That investing in human capital is important in promoting economic growth has been well emphasized in the literature. While the majority of Asian countries in our sample are investing around the average level of their income group, if not more, there are some countries like Malaysia, the Philippines, and Timor-Leste that invest substantially below the average.

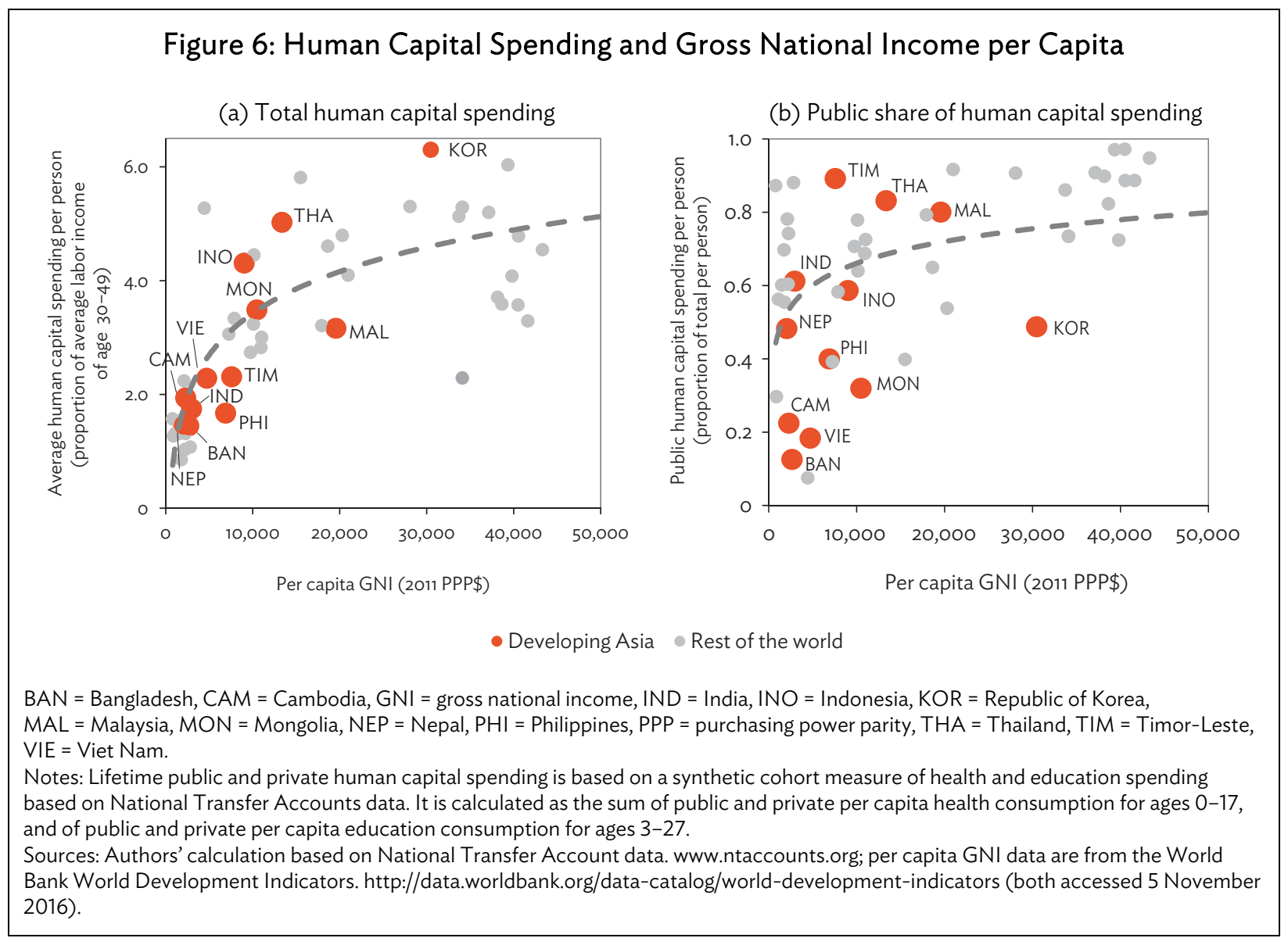

Second, the contribution of the public sector in human capital spending intensifies as countries develop (panel B). While there is wide variation in the government's share in human capital spending among developing countries, there is a clear upward trend as per capita gross national income increases. This shift toward an increasing role by governments in financing human capital investments has also been observed recently in health spending (Fan and Savedoff 2014), and much earlier in financing consumption in general (Peacock and Wiseman 1961).

What could be the potential impacts of increasing human capital spending? Figure 7 presents the simulated effects of a universal $20 \%$ increase in human capital spending per capita on labor productivity growth (panel A) and on income inequality (panel B) in 12 Asian countries. These countries are selected based on the availability of data needed to estimate the structural model presented in the previous section. The simulated increase in human capital spending per person roughly equals the magnitude of the projected drop in average births per woman in developing Asia countries in the next 3 decades. 
Figure 7: Simulated Impact of Increased Human Capital Spending

(a) Labor productivity growth (\%)

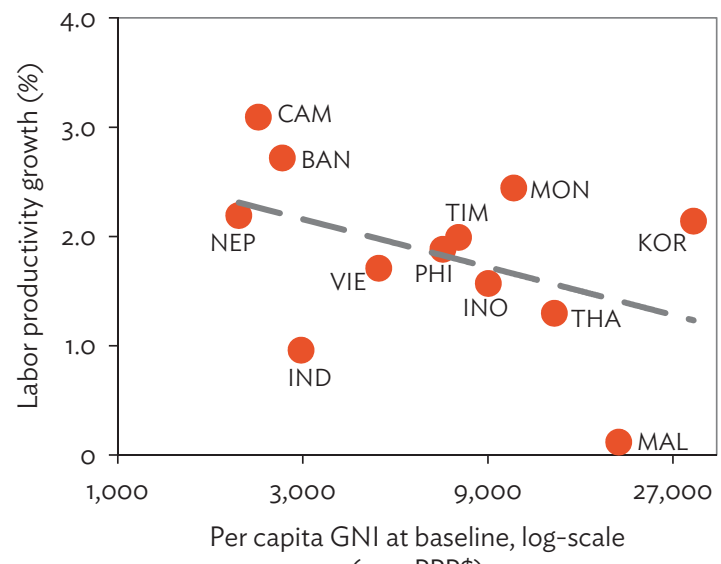

(2011 PPP\$) (b) Income inequality

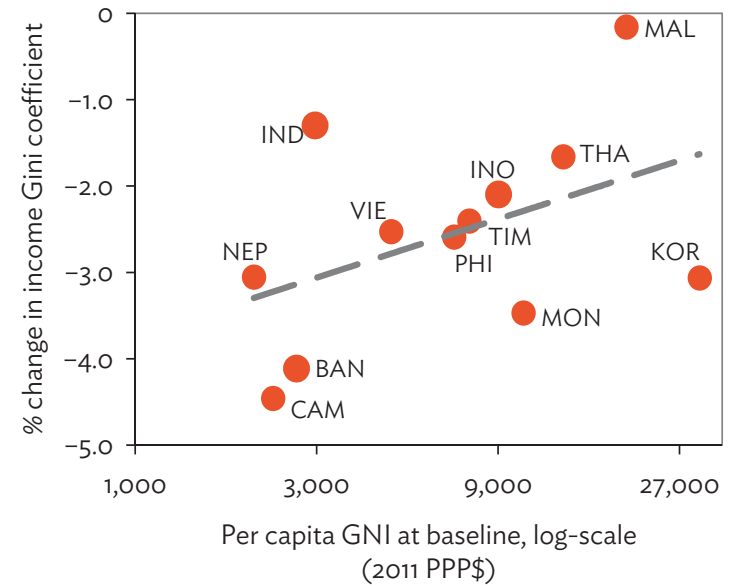

BAN = Bangladesh, $\mathrm{CAM}=$ Cambodia, $\mathrm{GNI}=$ gross national income, $\mathrm{IND}=$ India, $\mathrm{INO}=$ Indonesia, $\mathrm{KOR}=\mathrm{Republic}$ of Korea, $\mathrm{MAL}=$ Malaysia, $\mathrm{MON}=$ Mongolia, NEP = Nepal, $\mathrm{PHI}=$ Philippines, $\mathrm{PPP}=$ purchasing power parity, $\mathrm{THA}=\mathrm{Thailand}$, TIM = Timor-Leste, VIE $=$ Viet Nam.

Note: Simulated impact estimates are responses to a $20 \%$ increase in per capita human capital spending by age.

Sources: Authors' calculation based on National Transfer Account data. www.ntaccounts.org; per capita GNI data are from the World

Bank World Development Indicators. http://data.worldbank.org/data-catalog/world-development-indicators (both accessed 5 November 2016).

The projected impact by country shows some interesting patterns. Lower-income countries are likely to benefit more from increased human capital spending. Labor productivity in lower-income countries like Bangladesh, Cambodia, and Nepal is projected to increase by $2 \%-3.5 \%$ as a result of a $20 \%$ expansion of human capital spending per person. In more developed countries, like Malaysia and Thailand, the projected impact is more modest. It is quite interesting that, among countries with similar economic levels, for instance, Bangladesh and India, the projected impact of human capital spending on labor productivity can differ quite substantially, reflecting their different population age profiles of productivity. The simulated impact on productivity growth in the Republic of Korea and Nepal is about the same despite the huge disparity in income level, suggesting that human capital spending may still benefit higher-income countries despite the general reduction in impact as per capita income rises.

In addition, human capital spending has a significant impact on reducing inequality. Again, the impact is greatest among lower-income countries than in more-developed economies. In Bangladesh, Cambodia, Nepal, and Viet Nam, for instance, increased human capital spending is projected to bring down income Gini coefficients by 3\%-5\% relative to baseline values. In more developed Thailand and Malaysia, the impact is more modest, ranging from $1 \%$ to $2 \%$ drop.

The welfare impact of human capital spending may be traced to its greater impact on poorer households, especially in lower-income countries (Table 3). In Bangladesh and Cambodia, for instance, labor productivity among the poorest income quintile households is projected to increase by about 7\%$8 \%$. The impact on higher-income households is also substantial, but smaller. 
Table 3: Simulated Impact of Human Capital Spending on Productivity Growth and Inequality

\begin{tabular}{|c|c|c|c|c|c|c|c|c|}
\hline \multirow[b]{2}{*}{ Country } & \multicolumn{2}{|c|}{$\%$ Change in Inequality } & \multicolumn{6}{|c|}{$\begin{array}{c}\text { Productivity Growth Rate (\%) } \\
\text { by Income Quintile }\end{array}$} \\
\hline & $\begin{array}{l}\text { Human } \\
\text { Capital } \\
\end{array}$ & $\begin{array}{l}\text { Labor } \\
\text { Income }\end{array}$ & $\begin{array}{c}\mathrm{Q} 1 \\
\text { (poorest) }\end{array}$ & Q2 & Q3 & Q4 & $\begin{array}{c}\text { Q5 } \\
\text { (richest) }\end{array}$ & $\begin{array}{c}\text { All } \\
\text { Groups }\end{array}$ \\
\hline Bangladesh & -6.7 & -4.1 & 7.5 & 5.7 & 4.0 & 2.4 & 0.6 & 2.7 \\
\hline Cambodia & -7.2 & -4.5 & 7.4 & 6.1 & 4.6 & 2.8 & 0.8 & 3.1 \\
\hline India & -3.7 & -2.1 & 3.4 & 3.3 & 2.8 & 2.0 & 0.3 & 1.6 \\
\hline Indonesia & -2.3 & -1.3 & 2.3 & 2.2 & 1.9 & 1.3 & 0.2 & 1.0 \\
\hline Republic of Korea & -5.1 & -3.1 & 4.9 & 4.3 & 3.5 & 2.3 & 0.5 & 2.1 \\
\hline Malaysia & -0.3 & -0.2 & 0.3 & 0.3 & 0.3 & 0.2 & 0.0 & 0.1 \\
\hline Mongolia & -5.8 & -3.5 & 5.7 & 4.9 & 3.9 & 2.5 & 0.6 & 2.4 \\
\hline Nepal & -5.1 & -3.1 & 4.7 & 4.3 & 3.5 & 2.4 & 0.5 & 2.2 \\
\hline Philippines & -4.3 & -2.6 & 4.7 & 4.2 & 3.3 & 2.1 & 0.4 & 1.9 \\
\hline Thailand & -2.9 & -1.7 & 2.6 & 2.6 & 2.5 & 1.9 & 0.3 & 1.3 \\
\hline Timor-Leste & -4.5 & -2.4 & 3.5 & 3.5 & 3.3 & 2.8 & 0.6 & 2.0 \\
\hline Viet Nam & -4.1 & -2.5 & 4.7 & 3.9 & 2.9 & 1.7 & 0.3 & 1.7 \\
\hline
\end{tabular}

$Q=$ Income quintile.

Source: Authors' calculation.

The increase in worker productivity is expected to benefit the government as well. The fiscal effect of greater human capital spending depends on each country's tax structure inasmuch as it depends on the government's role in the increase in human capital spending and the effect of such spending on labor productivity. Personal income tax per capita in Cambodia and Timor-Leste, for instance, is projected to increase by at least 3\% (Table 4, panel A). In other countries, the projected impact on government revenues are economically insignificant despite large gains in labor productivity.

There are many different ways governments can intervene to increase human capital spending besides a universal increase in spending. For instance, governments may target human capital spending expansion only on vulnerable groups, while keeping current levels of spending on other groups. An alternative strategy could be to increase the efficiency of public spending without increasing the level of spending. These strategies are not mutually exclusive, and may be combined to create more targeted strategies.

For further analysis, we consider three types of targeted strategies. In the first strategy, we assume governments increase its spending per person by $20 \%$ of the average total human capital spending by age. We assume that there is no change in the government's efficiency in this scenario (strategy 1). In the second strategy, we assume a $20 \%$ increase in public efficiency in translating inputs to human capital, but we hold public spending at its baseline values (strategy 2). Finally, in the last scenario, we combine the two strategies, so there is a $20 \%$ increase in both human capital spending and human capital production efficiency (strategy 3). We then combine these three scenarios with three different government targeting schemes; namely, a universal program where every household benefits from public human capital interventions, and targeted programs that are available only to either the poorest $40 \%$ or poorest $60 \%$ of households. Table 4 summarizes the projected effects of different public human capital interventions on Asia.

In all of the strategies considered, government revenues are projected to increase, with labor income per capita growing by as much as 3\%-5\% in some scenarios in some countries. Increasing both public efficiency and public provision of human capital spending seems to result in greater increase in tax collection per capita, relative to the combined impact of separately pursuing each intervention. There is a modest negative change, if at all, in effective tax rates, indicating that household labor income will grow faster than the amount collected from them in taxes by the government. 
Table 4: Simulated Fiscal Impacts of Universal and Targeted Human Capital Interventions

\begin{tabular}{|c|c|c|c|c|c|c|c|c|c|}
\hline \multirow[t]{2}{*}{ Country } & \multicolumn{3}{|c|}{$\begin{array}{l}\text { Change in Effective Tax Tate } \\
\text { (percentage point difference) }\end{array}$} & \multicolumn{3}{|c|}{$\begin{array}{c}\text { Growth in Personal (Labor) Income } \\
\text { Tax Per Capita (\%) }\end{array}$} & \multicolumn{3}{|c|}{$\begin{array}{c}\text { Change in Gross Fiscal Rate of Return } \\
\text { (percentage point difference) }\end{array}$} \\
\hline & Universal & Lower 40 & Lower 60 & Universal & Lower 40 & Lower 60 & Universal & Lower 40 & Lower 60 \\
\hline \multicolumn{10}{|c|}{ A. Strategy 1: Increase public spending by $20 \%$ of total human capital spending per capita by age; no change in efficiency } \\
\hline Bangladesh & -0.04 & -0.02 & -0.03 & 0.27 & 0.00 & 0.00 & -3.26 & -1.66 & -2.28 \\
\hline Cambodia & 0.01 & 0.01 & 0.01 & 3.53 & 1.86 & 2.56 & -5.59 & -2.83 & -3.95 \\
\hline India & -0.05 & -0.02 & -0.04 & 0.01 & 0.00 & 0.00 & -0.93 & -0.41 & -0.59 \\
\hline Indonesia & -0.05 & -0.03 & -0.04 & 0.45 & 0.21 & 0.31 & -1.03 & -0.45 & -0.66 \\
\hline Republic of Korea & 0.00 & -0.01 & -0.01 & 2.17 & 1.00 & 1.45 & -1.09 & -0.48 & -0.71 \\
\hline Malaysia & -0.01 & 0.00 & -0.01 & 0.02 & 0.01 & 0.01 & -0.83 & -0.36 & -0.53 \\
\hline Mongolia & 0.00 & 0.00 & 0.00 & 2.45 & 1.26 & 1.77 & -1.82 & -0.83 & -1.21 \\
\hline Nepal & -0.05 & -0.03 & -0.04 & 0.73 & 0.30 & 0.44 & -1.49 & -0.67 & -0.97 \\
\hline Philippines & 0.00 & -0.01 & -0.01 & 0.47 & 0.23 & 0.35 & -2.41 & -1.10 & -1.58 \\
\hline Thailand & -0.10 & -0.05 & -0.08 & 0.15 & 0.00 & 0.00 & -0.69 & -0.30 & -0.44 \\
\hline Timor-Leste & 0.06 & 0.02 & 0.04 & 3.14 & 1.38 & 2.05 & -0.62 & -0.26 & -0.41 \\
\hline Viet Nam & -0.08 & -0.05 & -0.07 & 1.21 & 0.57 & 0.78 & -5.60 & -2.98 & -4.03 \\
\hline \multicolumn{10}{|c|}{ B. Strategy 2: Increase efficiency of public human capital inputs by $20 \%$; no change in public spending } \\
\hline Bangladesh & 0.00 & 0.00 & 0.00 & 0.03 & 0.00 & 0.00 & 0.00 & 0.00 & 0.00 \\
\hline Cambodia & 0.00 & 0.00 & 0.00 & 0.81 & 0.43 & 0.60 & 0.09 & 0.05 & 0.05 \\
\hline India & -0.03 & -0.01 & -0.02 & 0.01 & 0.00 & 0.00 & 0.00 & 0.00 & 0.00 \\
\hline Indonesia & -0.03 & -0.02 & -0.02 & 0.25 & 0.12 & 0.17 & 0.01 & 0.00 & 0.00 \\
\hline Republic of Korea & 1.64 & 0.00 & 0.00 & 0.96 & 0.42 & 0.62 & 0.03 & 0.01 & 0.01 \\
\hline Malaysia & -0.01 & 0.00 & 0.00 & 0.01 & 0.01 & 0.01 & 0.00 & 0.00 & 0.00 \\
\hline Mongolia & 0.00 & 0.00 & 0.00 & 0.83 & 0.42 & 0.59 & 0.04 & 0.02 & 0.02 \\
\hline Nepal & -0.02 & -0.01 & -0.02 & 0.36 & 0.15 & 0.21 & 0.02 & 0.01 & 0.01 \\
\hline Philippines & 0.00 & -0.01 & 0.00 & 0.18 & 0.08 & 0.13 & 0.01 & 0.01 & 0.01 \\
\hline Thailand & -0.08 & -0.04 & -0.07 & 0.13 & 0.00 & 0.00 & 0.00 & 0.00 & 0.00 \\
\hline Timor-Leste & 0.05 & 0.02 & 0.03 & 2.80 & 1.23 & 1.82 & 0.10 & 0.04 & 0.04 \\
\hline Viet Nam & -0.02 & -0.01 & -0.01 & 0.24 & 0.11 & 0.15 & 0.02 & 0.01 & 0.01 \\
\hline
\end{tabular}


Human Capital Spending, Inequality, and Growth in Middle-Income Asia | 17

Table 4 continued

\begin{tabular}{|c|c|c|c|c|c|c|c|c|c|}
\hline & \multicolumn{3}{|c|}{$\begin{array}{l}\text { Change in Effective Tax Rate } \\
\text { (percentage point difference) }\end{array}$} & \multicolumn{3}{|c|}{$\begin{array}{c}\text { Growth in Personal (Labor) Income } \\
\text { Tax Per Capita (\%) }\end{array}$} & \multicolumn{3}{|c|}{$\begin{array}{c}\text { Change in Gross Fiscal Rate of Return } \\
\text { (percentage point difference) }\end{array}$} \\
\hline & Universal & Lower 40 & Lower 60 & Universal & Lower 40 & Lower 60 & Universal & Lower 40 & Lower 60 \\
\hline \multicolumn{10}{|c|}{ C. Strategy 3: Increase in both public spending and efficiency of public human capital inputs } \\
\hline Bangladesh & -0.05 & -0.03 & -0.04 & 0.36 & 0.00 & 0.00 & -3.26 & -1.66 & -2.28 \\
\hline Cambodia & 0.02 & 0.02 & 0.02 & 4.96 & 2.60 & 3.57 & -5.47 & -2.76 & -3.88 \\
\hline India & -0.08 & -0.04 & -0.06 & 0.02 & 0.00 & 0.00 & -0.93 & -0.41 & -0.59 \\
\hline Indonesia & -0.09 & -0.05 & -0.07 & 0.80 & 0.36 & 0.53 & -1.02 & -0.45 & -0.66 \\
\hline Republic of Korea & 0.01 & 0.01 & 0.01 & 0.83 & 0.45 & 0.64 & -2.38 & -1.08 & -1.56 \\
\hline Malaysia & -0.02 & -0.01 & -0.01 & 0.03 & 0.02 & 0.02 & -0.83 & -0.36 & -0.53 \\
\hline Mongolia & 0.00 & 0.00 & 0.00 & 3.69 & 1.86 & 2.64 & -1.77 & -0.80 & -1.18 \\
\hline Nepal & -0.08 & -0.04 & -0.06 & 1.20 & 0.50 & 0.71 & -1.47 & -0.66 & -0.96 \\
\hline Philippines & 0.01 & -0.02 & -0.02 & 3.53 & 1.60 & 2.33 & -1.05 & -0.46 & -0.69 \\
\hline Thailand & -0.20 & -0.10 & -0.15 & 0.28 & 0.00 & 0.00 & -0.68 & -0.30 & -0.44 \\
\hline Timor-Leste & 0.12 & 0.05 & 0.07 & 6.45 & 2.80 & 4.19 & -0.50 & -0.21 & -0.36 \\
\hline Viet Nam & -0.12 & -0.07 & -0.10 & 1.64 & 0.77 & 1.07 & -5.57 & -2.96 & -4.01 \\
\hline
\end{tabular}

Source: Authors' estimates. 
On a per person basis, the overall rate of return from public spending on human capital relative to potential tax collections depends on the government strategy employed to raise human capital. In general, strategies that increase production efficiency without increasing inputs have little positive to no effect on the overall fiscal rate of return from public human capital spending (panel B). Increasing public spending is projected to decrease the overall fiscal rate of return (panels $A$ and $C$ ), although the rates remain positive in all scenarios.

\section{CONCLUDING OBSERVATIONS}

In this paper, we empirically examine the effect of human capital spending on economic growth, income inequality, and fiscal balance in Asia. To do so, we perform a case study of the Philippines using subnational data and simulate the impact of human capital spending on growth, inequality, and fiscal balance in 12 Asian economies. Asia's rapid population aging and its transformation into a middle-income region portend a bigger role for human capital in the region's future growth. The main channel through which human capital affects growth and inequality is through its effect on labor income. Improved labor productivity boosts output and income and, to the extent that the poor experience a larger improvement, it also helps to reduce income inequality. Although human capital spending is costly for governments, its positive impact on income expands the tax base and, thus, government revenues.

Our major source of data is the NTA database, which consists of household data that document economic flows across populations of different ages. The results of our empirical analysis indicate that human capital investment promotes both output growth and income equality in Asia, and thus contributes to more inclusive growth in the region. Poorer households experience a relatively larger increase in their labor income, which enables them to narrow the income gap with richer households. Further, the growth impact is larger for poorer Asian countries than for richer countries. We also find that public investment is more beneficial for equity than private investment. All in all, our evidence is consistent with the conventional wisdom that public spending on human capital fosters greater equality of opportunity. Further, our evidence suggests that the expansion of tax base and fiscal revenues more than offsets the cost of such spending. Overall, our evidence points to a positive effect of human capital on growth, equity, and fiscal balance in Asia.

It should be pointed out that our benign simulated outcomes are not a guarantee of benign actual outcomes. The extent to which human capital investment benefits economic growth, income inequality, and fiscal balance will depend in part on how human capital spending is transformed to productive labor. Thus, other government policies and the overall economic environment also come into play. For example, a more flexible labor market will facilitate the transformation of human capital into productive employment. We also looked at three different modes of government intervention on human capital; namely, a universal increase in human capital spending, a targeted increase in human capital spending only for vulnerable groups, and an increase in the efficiency of human capital spending. Again, it should be noted that these strategies are not mutually exclusive, and there is plenty of scope for combining them with each other to create better targeted strategies. The important issue of effectiveness of private versus public human capital spending on productivity growth is not much in detail here, and is left for future studies. 


\section{REFERENCES}

Abrigo, Michael R. M., Rachel H. Racelis, J. M. Ian Salas, and Alejandro N. Herrin. 2016. "Decomposing Economic Gains from Population Age Structure Transition in the Philippines." The Journal of the Economics of Ageing. http://dx.doi.org/10.1016/j.jeoa.2016.09.002

Aghion, Philippe, and Peter W. Howitt. 2009. The Economics of Growth. Cambridge, MA: The MIT Press.

Asian Development Bank (ADB). 2017. Asian Development Outlook 2017: Transcending the MiddleIncome Challenge. Manila.

2012. Asian Development Outlook 2012: Confronting Rising Inequality in Asia. Manila.

2011. Asian Development Outlook 2011 Update: Preparing for Demographic Transition. Manila.

Barro, Robert J. 2001. “Human Capital and Growth.” The American Economic Review 91 (2): 12-17.

Bloom, David E., and Jeffrey G. Williamson. 1998. "Demographic Transition and Economic Miracles in Emerging Asia.” World Bank Economic Review 12: 419-55.

Davoodi, Hamid R., Erwin R. Tiongson, and Sawitree Sachjapinan Asawanuchit. 2010. "Benefit Incidence of Public Education and Health Spending Worldwide: Evidence from a New Database." Poverty and Public Policy 2 (2): 5-52.

Fan, Victoria Y., and William D. Savedoff. 2014. "The Health Financing Transition: A Conceptual Framework and Empirical Evidence.” Social Science \& Medicine 105: 112-21.

Hanushek, Eric, and Ludger Woessmann. 2016. "Knowledge Capital, Growth, and the East Asian Miracle." Science 351 (6271): 344-45.

Kelley, Allen C., and Robert M. Schmidt. 2001. "Economic and Demographic Change: A Synthesis of Models, Findings, and Perspectives." In Population Matters: Demographic Change, Economic Growth, and Poverty in the Developing World, edited by Nancy Birdsall, Allen C. Kelley, and Steven Sinding. New York: Oxford University Press.

Lee, Ronald, Sang-Hyop Lee, and Andrew Mason. 2008. "Charting the Economic Lifecycle. In Population Ageing, Human Capital Accumulation, and Productivity Growth. A Supplement to Population and Development Review 33, edited by Alexia Prskawetz, David E. Bloom, and Wolfgang Lutz. New York: Population Council.

Lee, Ronald, and Andrew Mason. 2010. "Fertility, Human Capital, and Economic Growth over the Demographic Transition." European Journal of Population 26 (2): 159-82.

Lee, Ronald, and Andrew Mason, eds. 2011. Population Aging and the Generational Economy: A Global Perspective. Northampton, MA: Edward Elgar.

Lee, Sang-Hyop, Jungsuk Kim, and Donghyun Park. 2016. "Demographic Change and Fiscal Sustainability in Asia." Social Indicators Research. doi:10.1007/s11205-016-1424-0 
Manasan, Rosario G., Janet S. Cuenca, and Eden C. Villanueva-Ruiz. 2007. "Benefit Incidence of Public Spending on Education in the Philippines." Philippine Institute for Development Studies Discussion Paper No. 2007-09.

Mankiw, N. Gregory, David Romer, and David N. Weil. 1992. "A Contribution to the Empirics of Economic Growth.” Quarterly Journal of Economics 107 (2): 407-37.

Mason, Andrew, ed. 2001. Population Change and Economic Development in East Asia: Challenges Met, Opportunities Seized. Stanford, CA: Stanford University Press.

Mason, Andrew, and Ronald Lee. 2007. "Transfers, Capital, and Consumption over the Demographic Transition." In Population Aging, Intergenerational Transfers and the Macroeconomy, edited by Robert Clark, Naohiro Ogawa, and Andrew Mason. Cheltenhan, United Kingdom and Northampton, MA: Edward Elgar.

Mason, Andrew, Ronald Lee, and Jennifer Xue Jiang. 2016. "Demographic Dividends, Human Capital, and Saving." The Journal of the Economics of Ageing 7: 106-22.

Mason, Andrew, Ronald Lee, An-Chi Tung, Mun-Sim Lai, and Tim Miller. 2009. "Population Ageing and Intergenerational Transfers: Introducing Age into National Accounts." In Developments in the Economics of Aging, edited by David Wise. Chicago: National Bureau of Economic Research and University of Chicago Press.

Meghir, Costas, and Luigi Pistaferri. 2004. "Income Variance and Dynamics Heterogeneity." Econometrica 72 (1): 1-32.

Mejia-Guevara, Ivan. 2014. "Economic Inequality and Intergenerational Transfers: Evidence from Mexico." The Journal of the Economics of Ageing 5 (1): 23-32.

Mesa, Eirene P. 2007. "Measuring Education Inequality in the Philippines." The Philippine Review of Economics 44 (2): 33-70.

Miller, Tim, Paulo Saad, and Ciro Martinez. 2016. "Population Ageing, Demographic Dividend and Gender Dividend: Assessing the Long Term Impact of Gender Equality on Economic Growth and Development in Latin America." In Demographic Dividends: Emerging Challenges and Policy Implications." Demographic Transformation and Socio-Economic Development, edited by Roberta Pace and Roberto Ham-Chande, Volume 6, pp. 23-43. Springer.

Peacock, Alan T., and Jack Wiseman. 1961. The Growth of Public Expenditure in the United Kingdom. Princeton, NJ: Princeton University Press.

United Nations, Department of Economic and Social Affairs (UN DESA). 2013. National Transfer Accounts Manual: Measuring and Analyzing the Generational Economy. New York: United Nations.

World Bank. 2016. World Development Indicators. PPP conversion factor, GDP (LCU per international \$) (data file). http://data.worldbank.org/indicator/PA.NUS.PPP 


\section{Human Capital Spending, Inequality, and Growth in Middle-Income Asia}

Using data from the National Transfer Accounts, the authors analyze the impact of human capital spending on income inequality and economic growth in middle-income Asia. They find that human capital has a significant effect on labor productivity and, hence, output. The effect is more pronounced for poorer households, pointing to a positive link between human capital and inclusive growth in Asia.

\section{About the Asian Development Bank}

ADB's vision is an Asia and Pacific region free of poverty. Its mission is to help its developing member countries reduce poverty and improve the quality of life of their people. Despite the region's many successes, it remains home to a large share of the world's poor. ADB is committed to reducing poverty through inclusive economic growth, environmentally sustainable growth, and regional integration.

Based in Manila, ADB is owned by 67 members, including 48 from the region. Its main instruments for helping its developing member countries are policy dialogue, loans, equity investments, guarantees, grants, and technical assistance. 